\title{
Mature BDNF, But Not proBDNF, Reduces Excitability of Fast-Spiking Interneurons in Mouse Dentate Gyrus
}

\author{
Mai Marie Holm, ${ }^{1 \star}$ Jose Luis Nieto-Gonzalez, ${ }^{1 \star}$ Irina Vardya, ${ }^{1}$ Christian Bjerggaard Vaegter, ${ }^{2}$ Anders Nykjaer, ${ }^{2}$ \\ and Kimmo Jensen ${ }^{1}$ \\ ${ }^{1}$ Synaptic Physiology Laboratory, Department of Physiology and Biophysics, and 2MIND Center, Department of Medical Biochemistry, Aarhus University, \\ DK-8000 Aarhus, Denmark
}

\begin{abstract}
Mature BDNF and its precursor proBDNF may both be secreted to exert opposite effects on synaptic plasticity in the hippocampus. However, it is unknown how proBDNF and mature BDNF affect the excitability of GABAergic interneurons and thereby regulate GABAergic inhibition. We made recordings of GABAergic spontaneous IPSCs (sIPSCs) in mouse dentate gyrus granule cells and found that chronic or acute BDNF reductions led to large increases in the sIPSC frequencies, which were TTX (tetrodotoxin) sensitive and therefore action-potential driven. Conversely, addition of mature BDNF, but not proBDNF, within minutes led to a decrease in the sIPSC frequency to $44 \%$. Direct recordings from fast-spiking GABAergic interneurons revealed that mature BDNF reduced their excitability and depressed their action potential firing, whereas proBDNF had no effect. Using the TrkB inhibitor K-252a, or mice deficient for the common neurotrophin receptor $\mathrm{p} 75^{\mathrm{NTR}}$, the regulation of GABAergic activity was shown specifically to be mediated by BDNF binding to the neurotrophin receptor TrkB. In agreement, immunohistochemistry demonstrated that TrkB, but not p75 ${ }^{\mathrm{NTR}}$, was expressed in parvalbumin-positive interneurons. Our results suggest that mature BDNF decreases the excitability of GABAergic interneurons via activation of TrkB, while proBDNF does not impact on GABAergic activity. Thus, by affecting the firing of GABAergic interneurons, mature BDNF may play an important role in regulating network oscillations in the hippocampus.
\end{abstract}

\section{Introduction}

Brain-derived neurotrophic factor (BDNF) is an important signaling molecule in the mammalian CNS that plays a crucial role in the proper development and function of the CNS (Chao, 2003; Lu et al., 2005). In the adult CNS, BDNF is released from neurons and regulates synaptic plasticity, which is thought to underlie learning and memory, however, BDNF has also been implicated in pathophysiological events (Chao, 2003; Lu et al., 2005) such as epilepsy (Binder et al., 2001), bipolar disorders (Neves-Pereira et al., 2002), and schizophrenia (Pillai, 2008).

BDNF is synthesized in a pro-form by neurons, which can be cleaved into mature BDNF by intracellular proteases (Seidah et al., 1996; Matsumoto et al., 2008) or in the extracellular space (Pang et al., 2004). It was recently reported that both proBDNF and mature BDNF can be released by hippocampal neurons depending on the mode of stimulation. For instance, low-frequency stimulation resulted in proBDNF release and long-term depression (LTD) via p $75^{\text {NTR }}$ at excitatory synapses (Woo et al., 2005), whereas high-frequency stimulation favored BDNF release and TrkB-dependent long-term potentiation (LTP) in the

Received June 23, 2009; revised Aug. 11, 2009; accepted Aug. 17, 2009.

This study was supported by the Danish Medical Research Council (M.M.H., A.N., and K.J.), the Velux Foundation (K.J.), and the Lundbeck Foundation, Denmark (I.V., J.L.N.-G., K.J., and A.N.). We thank Lone Overgaard, Britt Malthesen, and Benedicte Vestergaard for excellent technical assistance.

${ }^{*}$ M.M.H. and J.L.N.-G. contributed equally to this work.

Correspondence should be addressed to Dr. Kimmo Jensen, Synaptic Physiology Laboratory, Department of Physiology and Biophysics, Building 1160, Aarhus University, DK-8000 Aarhus C, Denmark. E-mail: kimmo@fi.au.dk. DOI:10.1523/JNEUROSCI.2978-09.2009

Copyright $\odot 2009$ Society for Neuroscience ～0270-6474/09/2912412-07\$15.00/0
CA1 (Nagappan et al., 2009; Yang et al., 2009). Whether proBDNF and mature BDNF exert differential effects on the GABAergic system remains unknown.

While glutamatergic transmission is clearly regulated by BDNF, emerging evidence shows that GABAergic inhibition is also under the influence of this neurotrophin in a developmental and brain-region-specific manner (Woo and Lu, 2006). BDNF can upregulate or downregulate the function of $\mathrm{GABA}_{\mathrm{A}}$ receptors (Henneberger et al., 2002; Elmariah et al., 2004) or increase or decrease presynaptic inhibitory function (Olofsdotter et al., 2000; Baldelli et al., 2005). However, it is unknown whether BDNF affects the excitability of interneurons at the level of the cell body.

Here, we wanted to establish whether proBDNF or mature BDNF could alter the excitability of fast-spiking GABAergic interneurons and thereby regulate GABAergic inhibition. Second, we sought pharmacologically and immunohistochemically to determine whether these actions were mediated by the corresponding receptors $\mathrm{p} 75^{\mathrm{NTR}}$ or TrkB.

\section{Materials and Methods}

Mouse breeding. Mice were kept in a university animal facility with a $12 / 12 \mathrm{~h} \mathrm{light/dark}$ cycle with ad libitum access to food and water. Wildtype (WT) mice and genetically modified mice were bred on a C57BL/6J background. BDNF heterozygous (+/-) (Lyons et al., 1999) and p75 NTR KO mice (Lee et al., 1992) were described earlier. The p $75^{\text {NTR }}$ mutant mice still express a truncated form of the protein (von Schack et al., 2001 ); however, signaling by proBDNF via $75^{\text {NTR }}$ is disrupted (Woo et al., 2005).

Brain slice preparation. Male mice (P15-P25) were anesthetized with isoflurane, in accordance with Danish and European legislation regard- 
ing the use of laboratory animals. The mice were decapitated and the brains rapidly dissected out and transferred to ice-cold artificial CSF (ACSF) composed of the following (in $\mathrm{mm}$ ): $126 \mathrm{NaCl}, 2.5 \mathrm{KCl}, 2 \mathrm{CaCl}_{2}$, $2 \mathrm{MgCl}_{2}, 1.25 \mathrm{NaH}_{2} \mathrm{PO}_{4}, 26 \mathrm{NaHCO}_{3}, 10$ D-glucose (osmolality 305-315 $\left.\mathrm{mOsmol} \cdot \mathrm{kg}^{-1}\right)$, pH 7.4 when bubbled with carbogen $\left(5 \% \mathrm{CO}_{2} / 95 \%\right.$ $\mathrm{O}_{2}$ ). Coronal slices (350 $\mu \mathrm{m}$ thick) were cut on a Vibratome 3000 Plus (Vibratome), and slices were stored for at least $1 \mathrm{~h}$ at room temperature before recording. To improve slice viability, kynurenic acid (3 mM), ascorbate $(0.2 \mathrm{~mm})$, and pyruvate $(0.2 \mathrm{~mm})$ were present during slicing and storage. For further details, see Drasbek and Jensen (2006).

Electrophysiological patch-clamp recordings from dentate gyrus granule cells. Slices were placed in a recording chamber at $33 \pm 1^{\circ} \mathrm{C}$ and perfused with bubbled ACSF at $2-3 \mathrm{ml} \cdot \min ^{-1}$. Granule cells were identified in a custom-built infrared videomicroscope equipped with a $40 \times$ waterimmersion objective (Olympus). Patch pipettes were pulled from borosilicate glass (outer diameter $=1.5 \mathrm{~mm}$, inner diameter $=0.8 \mathrm{~mm}$ from Garner Glass) on a DMZ Universal Puller (Zeitz Instruments; resistance 3-5 $\mathrm{M} \Omega$ ) and filled with solution containing the following (in $\mathrm{mM}$ ): 140 $\mathrm{CsCl}, 2 \mathrm{MgCl}_{2}, 0.05$ EGTA, and 10 HEPES, pH 7.2 with $\mathrm{CsOH}$, osmolality $270-290 \mathrm{mOsmol} \cdot \mathrm{kg}^{-1}$ with sucrose. After obtaining stable gigaseals $(>1 \mathrm{G} \Omega$ ), whole-cell voltage-clamp recordings were made using a Multiclamp 700B amplifier. Series resistance and whole-cell capacitance were monitored and the recording discontinued if the series resistance increased by $50 \%$ or exceeded $20 \mathrm{M} \Omega$. Currents were low-pass filtered (eight-pole Bessel) at $3 \mathrm{kHz}$, digitized at $20 \mathrm{kHz}$, and acquired using a BNC-2110 DA converter and a PCI-6014 board (National Instruments) combined with a custom-written LabVIEW 6.1-based software (EVAN v. 1.4, courtesy of Istvan Mody, University of California, Los Angeles, Los Angeles, CA). Spontaneous IPSCs (sIPSCs) were detected using amplitude detection thresholds of $6-8 \mathrm{pA}$. Values are given as means \pm SEM, and $n$ stating the number of neurons. Paired or unpaired $t$ tests were used to assess statistical differences using a 5\% significance level and indicated by an asterisk $\left(^{*}\right)$ in the figures. Error bars show SEM.

Electrophysiological recordings and identification of interneurons. Current-clamp recordings were made from dentate gyrus interneurons (Jensen and Mody, 2001). Patch pipettes were filled with the following (in mM): $120 \mathrm{~K}$-gluconate, $10 \mathrm{KCl}, 10$ phosphocreatine disodium salt, 2 MgATP, 0.3 NaGTP, 0.1 EGTA, and 10 HEPES, pH 7.2 adjusted with $\mathrm{KOH}$, osmolality $280-290 \mathrm{mOsmol} \cdot \mathrm{kg}^{-1}$. All interneurons included for analysis showed a stable resting membrane potential of $-55 \mathrm{mV}$ or more negative, and action potentials that overshot $0 \mathrm{mV}$. The series resistance was noted at the beginning and end of the recording. Fastspiking basket cells were identified by the following criteria: (1) large pyramidal-shaped cells localized in the granule cell layer and orientation of the apical dendrite perpendicular to the granule cell layer; (2) a stuttering firing pattern around threshold; (3) high-frequency $(>50 \mathrm{~Hz})$ action potential frequency evoked by depolarizing current steps $(500 \mathrm{~ms}$, 100-400 pA) (Aponte et al., 2008); and (4) a coimmunostaining for biocytin and parvalbumin in a subset of neurons (Aponte et al., 2008).

Processing of biocytin-injected interneurons. Intracellular labeling was performed by including $0.5 \%$ biocytin in the internal pipette solution and the biocytin injection was facilitated by depolarizing current steps (0.2-1 nA) of $500 \mathrm{~ms}$ at $1 \mathrm{~Hz}$ for $10-20 \mathrm{~min}$ following data acquisition. Slices were transferred to a solution of $4 \%$ paraformaldehyde (PFA) at $4^{\circ} \mathrm{C}$ overnight, washed with PBS $(0.1 \mathrm{M}, \mathrm{pH} 7.3)$, and incubated overnight with FITC-conjugated avidin-D (Vector Laboratories) in PBS and $0.3 \%$ Triton X-100. Slices were then washed with PBS and embedded with fluorescent mounting medium (Dako) and labeled neurons visualized on a confocal laser microscope (Zeiss LSM510). The majority of the biocytin-injected neurons showed axonal branching within the granule cell layer.

Immunohistochemistry for parvalbumin was performed after the biocytin injection. Slices were transferred to PFA $4 \%$ overnight at $4^{\circ} \mathrm{C}$ and washed with PBS and incubated in a blocking solution comprised of 3\% normal donkey serum and 0.3 Triton X-100 in PBS during $1 \mathrm{~h}$ at room temperature. Slices were incubated in primary monoclonal antibody goat anti-parvalbumin (Swant, 1:500) in PBS containing 3\% normal donkey serum and $0.3 \%$ Triton X-100 for $24 \mathrm{~h}$ at $4^{\circ} \mathrm{C}$. After washing with PBS, slices were incubated with the secondary antibody (Donkey anti-goat-
A sIPSCs

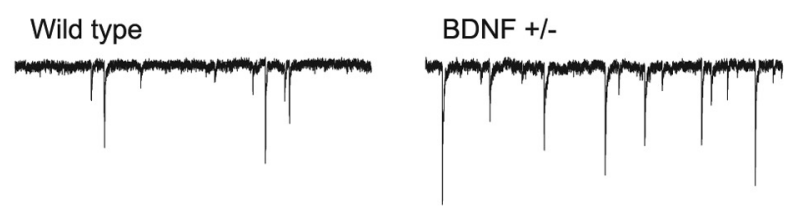

B

sIPSCs
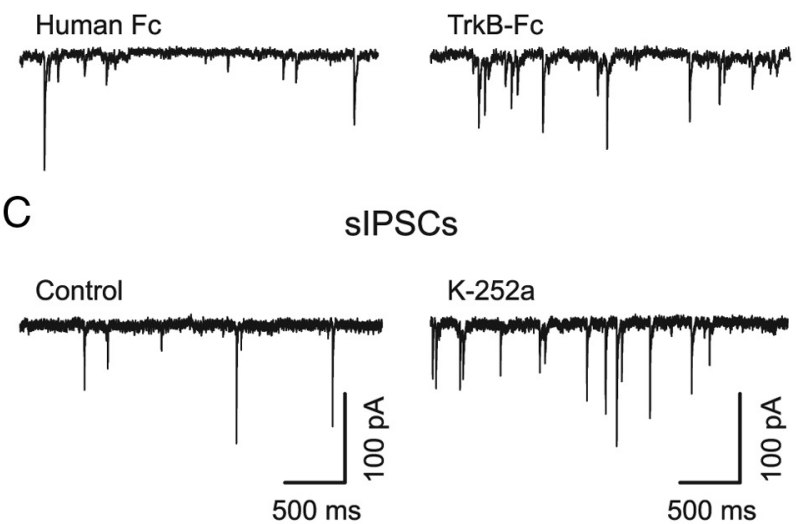

D

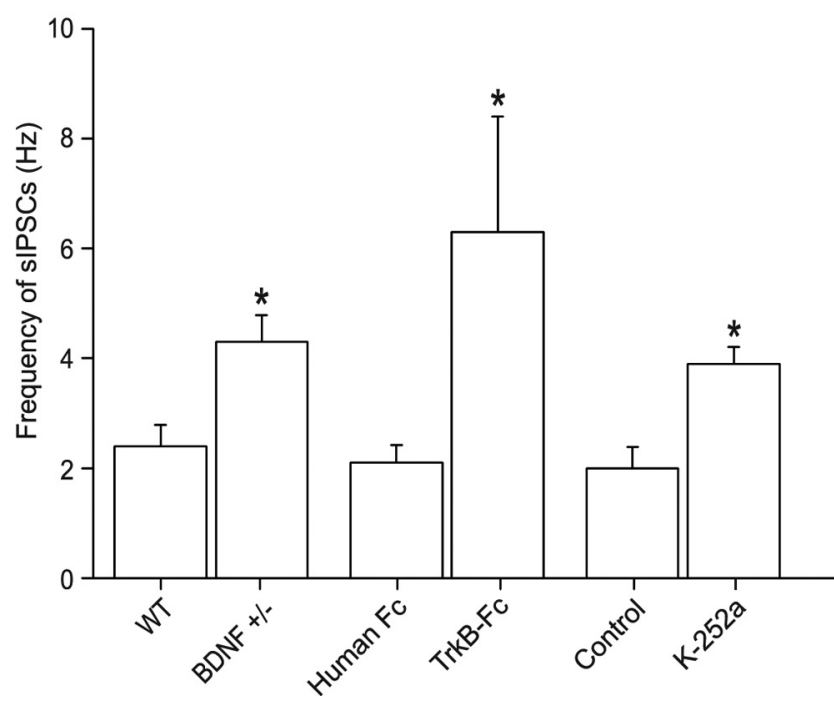

Figure 1. Chronic or acute reductions in BDNF lead to increased frequency of spontaneous IPSCS in granule cells involving TrkB receptors. Whole-cell recordings of GABAergic IPSCs in granule cells of the mouse dentate gyrus. $\boldsymbol{A}$, Spontaneous $\mathrm{GABA}_{\mathrm{A}}$ receptor-mediated IPSCs recorded in WT and BDNF+ / - mice. The action-potential-driven sIPSCs recorded without TTX showed a substantial increase by $65 \%$ in BDNF $+/$ - slices. $\boldsymbol{B}$, Brain slices from WT mice were incubated with either a control antibody (human $\mathrm{Fc}, 0.74 \mu \mathrm{g} / \mathrm{ml})$ for 4 h or $\operatorname{TrkB}-\mathrm{Fc}(2.2 \mu \mathrm{g} / \mathrm{ml})$. In TrkB-Fc, the sIPSC frequency was $200 \%$ larger than with human FC. C, Recordings of sIPSCs in control, and in a slice where K-252a (200 nm) was used to inhibit TrkB. The latter slices were incubated with $\mathrm{K}-252 \mathrm{a}$ for $1 \mathrm{~h}$, while control slices were incubated for $1 \mathrm{~h}$ with vehicle. $\mathrm{K}-252 \mathrm{a}$ increased the sIPSC frequency by $95 \%$. D, Histogram summarizing the frequency of sIPSCs.

Alexa 568, 1:500, Invitrogen) with FITC-conjugated avidin-D in PBS and $0.3 \%$ Triton X-100 at $4^{\circ} \mathrm{C}$ overnight. Following a second wash, slices were embedded with fluorescent mounting medium and visualized in a confocal microscope (see supplemental Fig. 1, available at www.jneurosci. org as supplemental material).

Immunohistochemistry for TrkB and $p 75^{N T R}$. Male WT mice (P18) and transgenic mice expressing GFP in somatostatin-positive interneurons (P20) (Oliva et al., 2000) were perfused with PBS followed by $4 \%$ PFA in PBS for $5 \mathrm{~min}$ and postfixed in the same fixative for $3 \mathrm{~h}$. After overnight 
incubation in 25\% sucrose in PBS the whole brain was snap frozen in isopentane/dry ice before cryosectioning at $30 \mu \mathrm{m}$ and mounted on Superfrost Plus slides. Sections were blocked in blocking buffer ( $5 \%$ fetal calf serum or normal donkey serum with $0.3 \%$ Triton X-100 in PBS) at room temperature for $1 \mathrm{~h}$ before incubation with the appropriate primary antibodies in blocking buffer for $2 \mathrm{~d}$ at $4^{\circ} \mathrm{C}$ : goat antiparvalbumin 1:500 (PVG-214, SWANT) and rabbit anti-TrkB 1:150 (Santa Cruz Biotechnology), rabbit anti-p75 ${ }^{\text {NTR }}$ 1:1500 (MC9651, a gift from Moses Chao, Skirball Institute, New York, NY) or anti-GFP 1:1000 (Abcam). Sections were incubated with the appropriate secondary antibody (donkey anti-rabbit Alexa 488, donkey anti-goat Alexa 568, donkey antirabbit Alexa 555 and donkey anti-goat Alexa 488 , all at 1:500, Invitrogen) in blocking buffer for $2 \mathrm{~h}$ at room temperature and mounted with fluorescence mounting media (Dako) or DAPI mounting media (Vectashield). Images were acquired on a Zeiss LSM510 microscope using a $10 \times$ or $40 \times$ objective and $405 / 488 / 543 \mathrm{~nm}$ laser lines (multitrack configuration). Images were processed ( $Z$-stack overlay) using the Zeiss LSM Image software. TrkB and $\mathrm{p} 75^{\text {NTR }}$ immunostainings were verified by parallel staining in dorsal root ganglia showing prominent staining for both proteins.

Drugs and solutions. All drugs and chemicals were from Sigma-Aldrich except for TTX and cleavage-resistant proBDNF (Alomone), and recombinant human TrkB-Fc chimera (\#688TK) and recombinant human IgG1-Fc (\#110-

HG) (R\&D Systems). K-252a was dissolved in distilled water in stock solution at $0.2 \mathrm{~mm}$ and diluted in ACSF to a final concentration of 200 nм. Mature BDNF and proBDNF was dissolved in ACSF in stock solutions at $5 \mu \mathrm{g} / \mathrm{ml}$. Mature BDNF was diluted into a final concentration of $10 \mathrm{ng} / \mathrm{ml}$, while proBDNF was used either at $2 \mathrm{ng} / \mathrm{ml}$ (Woo et al., 2005) or $10-20 \mathrm{ng} / \mathrm{ml}$.

\section{Results}

The frequency of spontaneous IPSCs is upregulated in dentate gyrus granule cells in $\mathrm{BDNF}+/-$ mice

Spontaneously arriving GABAergic synaptic input onto dentate gyrus granule cells mainly arise from perisomatic boutons originating from local interneurons (Soltesz et al., 1995). Earlier recordings of miniature IPSCs (mIPSCs) in the presence of TTX showed that the granule cell mIPSC frequency was increased by $53 \%$ in $\mathrm{BDNF}+/-$ mice compared with WT with no change in amplitude or kinetics (Olofsdotter et al., 2000). We first confirmed that the frequency of mIPSCs was upregulated in dentate gyrus of BDNF+/ - mice. Recordings were performed at a $V_{\text {hold }}$ of $-70 \mathrm{mV}$ using $\mathrm{CsCl}$-filled patch pipettes. In the presence of TTX $(1 \mu \mathrm{M})$ and the ionotropic glutamate receptor antagonist kynurenic acid ( $3 \mathrm{~mm}$ ), the mIPSC frequency in granule cells was slightly increased in BDNF+/- mice, from $1.8 \pm 0.22 \mathrm{~Hz}$ $(n=11)$ in WT to $2.4 \pm 0.34 \mathrm{~Hz}(n=4)$ in BDNF+/-, i.e., by $33 \%$ ( $p<0.05$, data not shown). Withdrawal of TTX from the extracellular medium to allow for action-potential firing in interneurons (Fig. $1 A$ ) resulted in a significant upregulation in the frequency of spontaneous $\mathrm{GABA}_{\mathrm{A}}$ receptor-mediated IPSCs (sIPSCs) from $2.4 \pm 0.38 \mathrm{~Hz}(n=11)$ in WT slices to $4.3 \pm 0.48$ $\mathrm{Hz}(n=10, p<0.05)$ in BDNF+/ - slices, i.e., by $65 \%$ (Fig. $1 D)$. The TTX sensitivity of the increased sIPSC frequency indicates that the interneuron firing was increased in the BDNF-deficient animals.

Incubation of slices with the BDNF scavenger, TrkB-Fc, increases the sIPSC frequency in WT granule cells

To confirm that the increase of sIPSCs in BDNF+/- mice was not caused by developmental or compensatory mechanisms in our preparation, we acutely reduced the mature BDNF levels in WT slices using TrkB-Fc (Shelton et al., 1995). Incubation of WT slices with TrkB-Fc $(2.2 \mu \mathrm{g} / \mathrm{ml})$ for 3-5 h dramatically increased the sIPSC frequency in granule cells by $200 \%$ (to $6.3 \pm 2.1 \mathrm{~Hz}$, $n=6)$ compared with incubating with a control substance $(0.74$ $\mu \mathrm{g} / \mathrm{ml}$ human FC, $2.1 \pm 0.32 \mathrm{~Hz}, n=9$ ) (Fig. $1 B, D$ ). The large increase in sIPSC frequency again gives evidence for increased interneuron firing under low BDNF conditions.

The TrkB inhibitor K-252a increases the sIPSC frequency and mimics BDNF deficiency in WT slices

Since TrkB has been shown to be expressed in interneurons (Cellerino et al., 1996), we tested whether the TrkB inhibitor K-252a (Knüsel and Hefti, 1992) could mimic the deficient state above. Incubation of WT slices for $1 \mathrm{~h}$ with K-252a (200 nM) increased the frequency of sIPSCs to $3.9 \pm 0.31 \mathrm{~Hz}(n=9)$, compared with $2.0 \pm 0.39 \mathrm{~Hz}$ in slices incubated for $1 \mathrm{~h}$ with vehicle alone $(n=9)$ (Fig. $1 C, D)$, i.e., an increase by $95 \%$. This indicates that $\mathrm{BDNF}$ exerts its actions on interneurons via TrkB receptors.

\section{Mature BDNF, but not proBDNF, reduces the sIPSC frequency}

Because mature BDNF and proBDNF elicit opposing activities in the hippocampal area CA1 on LTP and LTD, we next tested 
whether proBDNF might also affect GABAergic activity. We measured the sIPSC frequency in slices perfused with either mature BDNF or proBDNF (Fig. 2). In nine WT slices, the basal sIPSC frequency was $2.0 \pm 0.3 \mathrm{~Hz}$. Perfusion of mature BDNF decreased the frequency by $56.8 \pm 16.2 \%(n=5, p<0.05)$. In contrast, a cleavage-resistant form of proBDNF ( $2 \mathrm{ng} / \mathrm{ml}$ ) had no effect on the sIPSC frequency (Fig. $2 B$ ) (reduced by $6.2 \pm 3.2 \%$, $n=4, p>0.05$ ). Increasing the proBDNF concentration to 20 $\mathrm{ng} / \mathrm{ml}$ (Fig. $2 B$ ) did not affect on sIPSC frequency (reduced by $5.3 \%$ and $2.3 \%, n=2$ ). Furthermore, the effect of mature BDNF was independent of the neurotrophin receptor p $75^{\mathrm{NTR}}$, since mature BDNF still depressed the sIPSC frequency to the same extent in mice deficient for $\mathrm{p} 75^{\mathrm{NTR}}$. In $\mathrm{p} 75^{\mathrm{NTR}}$-deficient mice, the basal sIPSC frequency was $1.8 \pm 0.12 \mathrm{~Hz}(n=7)$ and mature BDNF reduced the frequency by $50.1 \pm 13.8 \%(p<0.05)$. These data suggest that mature BDNF depresses GABAergic inhibition via TrkB, while proBDNF signaling apparently plays no role (Fig. $2 D$ ).

\section{Direct recordings from fast-spiking GABAergic basket cells}

Since an important part of the sIPSCs is believed to arise from activity of fast-spiking basket cells (Williams et al., 1998), we made direct recordings from putative basket cells in dentate gyrus. Under infrared video microscopy (supplemental Fig. $1 \mathrm{~A}$, available at www.jneurosci.org as supplemental material) putative basket cells displayed a rounded, ovoid or triangular cell soma with a prominent apical dendrite perpendicular to the granule cell layer. In WT slices, these interneurons exhibited a resting membrane potential of $-63.1 \pm 1.36 \mathrm{mV}(n=8)$, displayed an unstable or stuttering firing pattern around threshold, high-frequency action potential firing $\left(>50\right.$ spikes $\left.\cdot \mathrm{s}^{-1}\right)$ during sustained depolarizing current pulses, and lacked fast adaptation (supplemental Fig. $1 B$, available at www.jneurosci.org as supplemental material). Frequency-intensity plots showed that relatively high current injections were needed to fire these neurons and that the firing frequency usually exceeded $100 \mathrm{~Hz}$ (supplemental Fig. $1 C$, available at www.jneurosci.org as supplemental material). All interneurons included displayed a fast-spiking firing pattern, and the majority was furthermore injected via biocytin to show the axonal arborization in the granule cell layer. A subset of basket cells $(n=5)$ was immunostained and found to be positive for parvalbumin (supplemental Fig. $1 D$, available at www. jneurosci.org as supplemental material). Based on these characteristics, the neurons were classified as fast-spiking basket cells.

\section{Excitability of fast-spiking basket cells is depressed by mature} BDNF, but not by proBDNF

Then, we analyzed the effect of mature BDNF and proBDNF on the excitability of basket cells. Depolarizing current injections of $500 \mathrm{~ms}$ were maintained throughout the whole experiment, and evoked action potential firing at $\sim 6-12 \mathrm{~Hz}$. Figure $3 A$ shows that the number of evoked spikes in a basket cell at 0 min and $8 \mathrm{~min}$ (also plotted in Fig. $3 D$, open circles). Figure 3, $B$, and $C$, depicts two basket cells before and after bath perfusion of either mature BDNF $(10 \mathrm{ng} / \mathrm{ml})$ or proBDNF $(10 \mathrm{ng} / \mathrm{ml})$. The depolarizing current pulses were maintained throughout the whole exposure, showing a significant reduction in the spike count after $8 \mathrm{~min}$ mature BDNF (Fig. $3 B$ ) with no change in the control cells or following proBDNF (Fig. 3D, filled and hatched circles, respectively). On average, the number of evoked action-potentials changed from $10.3 \pm 0.6$ to $10.0 \pm 0.8$ for controls $(n=4)$. Mature BDNF decreased the number of spikes from $8.6 \pm 1.2$ to $2.3 \pm 0.2(n=6)$. For proBDNF, the number of spikes did not change at $2 \mathrm{ng} / \mathrm{ml}$ (from $10.5 \pm 2.6$ spikes to $10.4 \pm 2.6, n=4$ ),
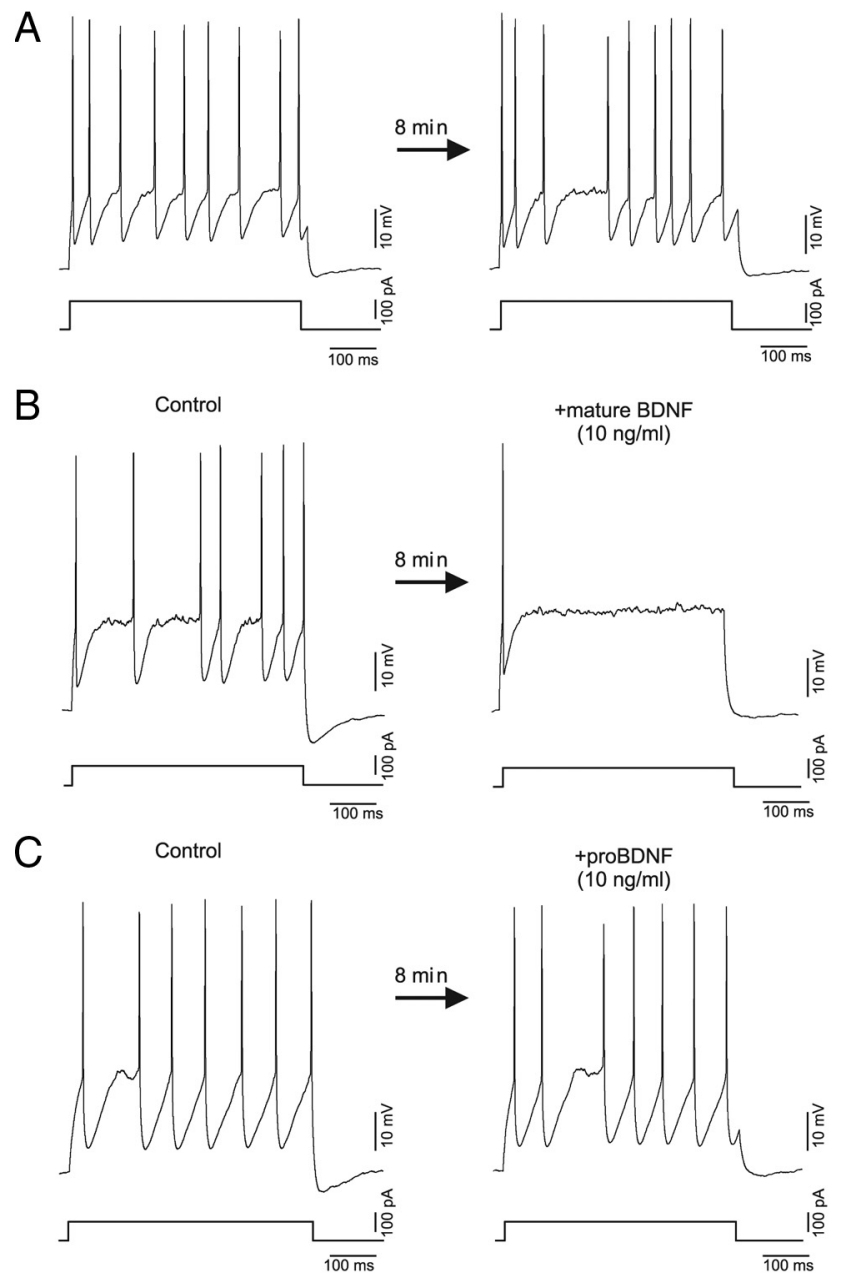

$(10 \mathrm{ng} / \mathrm{ml})$
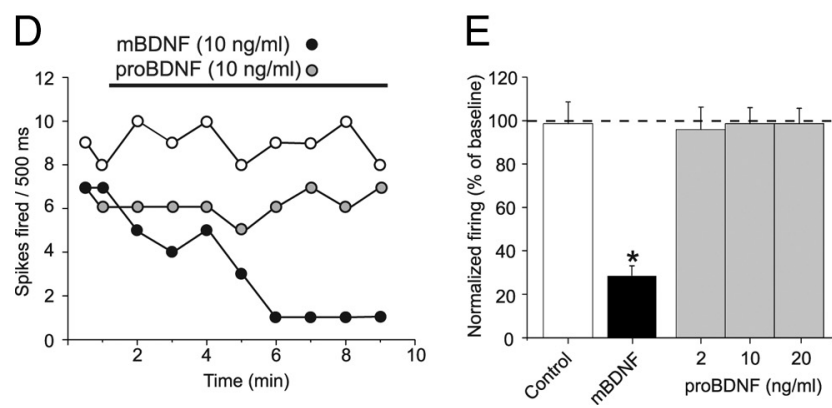

Figure 3. Mature BDNF, but not proBDNF, depresses the excitability of fast-spiking basket cells. $\boldsymbol{A}$, Current-clamp recording from a basket cell depolarized by current pulses showing a stable firing at the beginning (left) and after $8 \mathrm{~min}$ (right). $\boldsymbol{B}, \boldsymbol{C}$, Recordings showing the firing after bath perfusion of mature BDNF $(10 \mathrm{ng} / \mathrm{ml})$ or proBDNF $(10 \mathrm{ng} / \mathrm{ml})$. Mature BDNF depressed the firing, whereas proBDNF had no effect. $\boldsymbol{D}$, Time course of the neurons illustrated in $\boldsymbol{A}-\boldsymbol{C}$. The firing was reduced from 8 spikes to 1 spike by mature BDNF (filled circles), while there were no change in the time-matched control (open circles) or proBDNF (hatched circles). $\boldsymbol{E}$, Histogram summarizing the normalized action potential firing after $8 \mathrm{~min}$ in control $(n=4)$, mature BDNF $(10 \mathrm{ng} / \mathrm{ml}, n=6)$, and proBDNF ( $2 \mathrm{ng} / \mathrm{ml}, n=6 ; 10 \mathrm{ng} / \mathrm{ml}, n=7$, and $20 \mathrm{ng} / \mathrm{ml}, n=3)$. The number of evoked spikes was depressed by mature BDNF by $71 \%$.

at $10 \mathrm{ng} / \mathrm{ml}$ (from $6.4 \pm 0.5$ spikes to $6.2 \pm 0.6, n=7$ ), or at 20 $\mathrm{ng} / \mathrm{ml}$ (from $7.6 \pm 1.2$ spikes to $7.5 \pm 1.6, n=3$ ). Figure $3 E$ summarizes the number of spikes at $8 \mathrm{~min}$ normalized to the initial number of spikes. Following mature BDNF treatment, basket cells showed a small, but nonsignificant, hyperpolarization of the membrane potential $(-61.0 \pm 3.8 \mathrm{vs}-63.8 \pm 2.5 \mathrm{mV}, n=5$, $p>0.05)$, with no change in spike half-width $(1.11 \pm 0.033$ vs 
$1.14 \pm 0.012 \mathrm{~ms}, p>0.05)$ or input resistance $(142.5 \pm 19.1 \mathrm{M} \Omega$ vs $147.6 \pm 16 \mathrm{M} \Omega$, $p>0.05)$. Since mature BDNF reduced the excitability of the fast-spiking basket cells, we suggest that this mechanism participates in the reduction of sIPSCs via TrkB receptors in the dentate gyrus.

TrkB, but not $\mathrm{p} 75^{\mathrm{NTR}}$, colocalizes with parvalbumin in dentate gyrus

Finally, we performed double immunostainings for TrkB and parvalbumin, the latter being a calcium-binding protein expressed by fast-spiking basket cells. In the granule cell layer, parvalbumin staining (Fig. 4A, arrow) colocalized with TrkB immunoreactivity (Fig. 4C,D). All parvalbumin-positive cells observed in five different brain sections were positive for TrkB. In contrast, all basket cells were devoid of the proBDNF receptor $\mathrm{p} 75^{\mathrm{NTR}}$ (Fig. $4 E-H$ ), which may well explain the inability of these neurons to respond to proBDNF. Another major subclass of GABAergic interneurons expressing somatostatin was also negative for $\mathrm{p} 75^{\mathrm{NTR}}$ (supplemental Fig. 2, available at www. jneurosci.org as supplemental material). In fact, no p $75^{\mathrm{NTR}}$-positive cell bodies could be observed in typical localizations, where GABAergic interneurons are normally found in the hippocampus or cortex (Freund and Buzsáki, 1996).

Collectively, our data show that the activity of fast-spiking parvalbumin-positive interneurons is selectively regulated by binding of the mature form of BDNF to TrkB.

\section{Discussion}

Our study shows that mature BDNF, but not proBDNF, depresses the excitability of fast-spiking interneurons in the dentate gyrus, accompanied by a decrease in IPSCs in postsynaptic cells. The effect of mature BDNF on GABAergic inhibition was inhibited by soluble TrkB-Fc and the TrkB inhibitor K-252a. Also, TrkB protein could be immunohistochemically detected in parvalbumin-positive interneurons. We found that the proBDNF receptor p75 ${ }^{\mathrm{NTR}}$ is not expressed in interneurons, an observation that is in accordance with the inability of proBDNF to modulate GABAergic activity. Altogether, this suggests that mature BDNF, but not proBDNF, reduces interneuron excitability via TrkB.
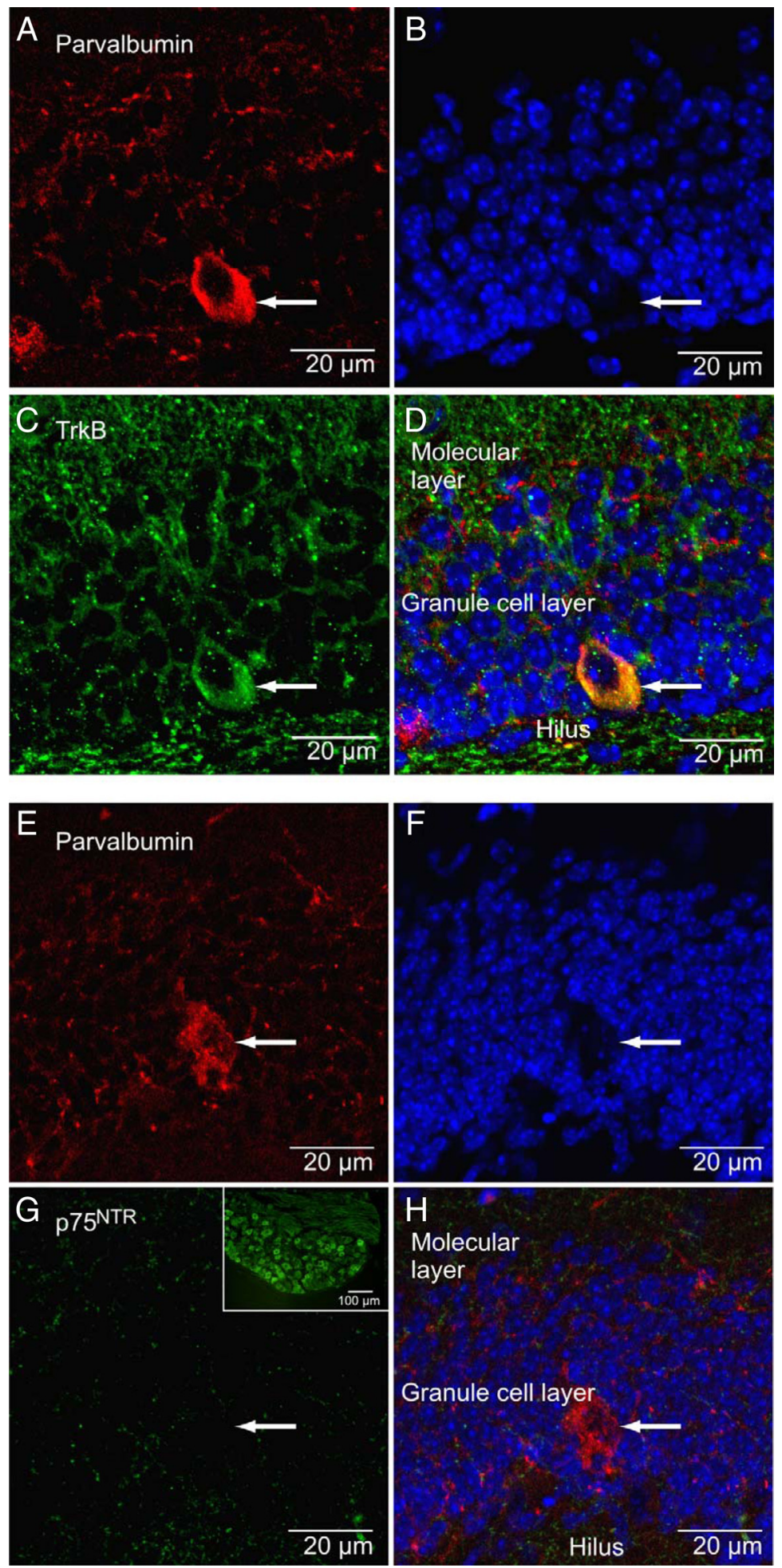

Figure 4. TrkB, but not p $75^{\text {NTR }}$, colocalizes with parvalbumin in the dentate gyrus. $A$, Immunostainings for parvalbumin (red) revealing large basket cells in the granule cell layer of the mouse dentate gyrus. The basket cell soma is indicated by arrows in all panels. B, DAPI (blue) nuclear staining of the granule cell layer. C, Staining for TrkB (green) shows immunoreactivity in granule cells and in basket cells. $\boldsymbol{D}$, Overlay showing colocalization of TrkB and parvalbumin in the basket cell. $\boldsymbol{E}$, Parvalbumin staining (red) of another basket cell. $\boldsymbol{F}$, DAPI nuclear staining. G, Immunostaining for $\mathrm{p} 75^{\mathrm{NTR}}$ (green) shows weak diffuse staining (positive control from dorsal root ganglion inserted). $\boldsymbol{H}$, Overlay showing no colocalization of $p 75^{\mathrm{NTR}}$ with parvalbumin.

\section{Signaling in the dentate gyrus by mature BDNF} versus proBDNF

BDNF signaling in the dentate gyrus is thought to be very important, since it can regulate neuronal morphology (Chen et al.,
2006) and neuronal activity, which can modify the excitability of this brain region, that serves as a gatekeeper into the hippocampus (Binder et al., 2001). Accordingly, dentate gyrus BDNF signaling is involved in several pathophysiological conditions, 
and in the response to antidepressant treatment (Wang et al., 2008).

In the CA1 area of the hippocampus, it is reported that secreted proBDNF has a distinct function, since it signals via p $75^{\mathrm{NTR}}$ to induce LTD (Woo et al., 2005), while mature BDNF signals via TrkB to induce LTP. On this background, we investigated whether mature BDNF and proBDNF could differentially affect the GABAergic system in the hippocampus.

Although some groups support the idea that proBDNF cannot be released in considerable amounts (Matsumoto et al., 2008), Yang et al. (2009) found that high levels of proBDNF are in fact detected in the axons of dentate gyrus granule cells. Therefore these neurons are able of accumulating proBDNF in subcellular compartments, and these authors suggested that hippocampal neurons can release proBDNF locally. Interestingly, we found that GABAergic dentate gyrus interneurons were not able of responding to proBDNF, which might have altered their excitability, and interneurons were not equipped with $\mathrm{p} 75^{\mathrm{NTR}}$ receptors (Dougherty and Milner, 1999). In contrast, BDNF released from granule cells would, according to our findings, have all prerequisites to depress interneuron excitability in its mature form via TrkB. Therefore, in these cells we can rule out a model where mature BDNF and proBDNF differentially affect GABAergic activity. Since the GABAergic function, at least in some conditions, is a strong regulator of the induction of LTP and LTD (Chevaleyre and Castillo, 2003), our findings are important for obtaining a unifying concept of mature BDNF and proBDNF signaling in the hippocampus.

\section{BDNF depresses GABAergic synaptic transmission via presynaptic and postsynaptic mechanisms}

BDNF has previously been found to affect GABAergic synapses. BDNF acutely depresses the amplitude of evoked IPSCs, reduces paired-pulse depression (Frerking et al., 1998), and reduces the frequency of miniature IPSC (Olofsdotter et al., 2000), all pointing to a presynaptic effect of BDNF. Postsynaptically, BDNF destabilizes $\mathrm{GABA}_{\mathrm{A}}$ receptor surface expression (Henneberger et al., 2002), and interferes with $\mathrm{Cl}^{-}$homeostasis via inhibition of KCC2 (Rivera et al., 2002). Our study is the first to show that mature BDNF directly depresses the excitability of interneurons.

\section{BDNF depresses the excitability of interneurons}

Since mature BDNF reduced TTX-sensitive sIPSCs in granule cells, we interpret this as a reduction of interneuron firing by BDNF. Since TrkB receptors, but not p $75^{\mathrm{NTR}}$, are expressed in parvalbumin-positive interneurons (Cellerino et al., 1996) (Fig. 4), the mature BDNF and TrkB pathway seems to be the most prominent way of acutely controlling the activity of this cell type. To determine the effects of BDNF on the somatodendritic excitability, we performed direct recordings from fast-spiking basket cells. Mature BDNF, but not proBDNF, depressed the excitability of these cells within minutes, as the number of evoked action potentials was reduced. No significant changes were observed in spike shape, membrane potential, or input resistance, arguing against a significant opening of leak channels that could prevent repetitive firing. Although the exact mechanism remains unknown, it is likely to involve voltage-activated conductances, including those mediated by $\mathrm{Na}^{+}$or $\mathrm{K}^{+}$channels.

\section{Perspectives}

Our results point to a reduction of GABAergic interneuron excitability by mature BDNF via TrkB receptors, and the findings consolidate the concept that BDNF is disinhibitory in the dentate gyrus. Thus, BDNF released from granule cells may diminish GABAergic inhibition and lead to hyperexcitability. It is therefore likely that increased BDNF, as seen in epilepsy, contributes to the hyperexcitable state, i.e., is proepileptic. Conversely, in BDNFdeficient states, as seen in animal models and patients with anxiety-depressive disorders (Chen et al., 2006), interneurons might be hyperactive which could contribute to the cognitive deficits seen in these conditions. Since the firing rate of basket cells controls the oscillatory rhythms of principal neurons (Bartos et al., 2002; Klausberger et al., 2003), the regulation of interneuron excitability by mature BDNF, but not proBDNF, could have a profound effect on the network function of the brain.

\section{References}

Aponte Y, Bischofberger J, Jonas P (2008) Efficient Ca2 + buffering in fastspiking basket cells of rat hippocampus. J Physiol 586:2061-2075.

Baldelli P, Hernandez-Guijo JM, Carabelli V, Carbone E (2005) Brainderived neurotrophic factor enhances GABA release probability and nonuniform distribution of $\mathrm{N}$ - and P/Q-type channels on release sites of hippocampal inhibitory synapses. J Neurosci 25:3358-3368.

Bartos M, Vida I, Frotscher M, Meyer A, Monyer H, Geiger JR, Jonas P (2002) Fast synaptic inhibition promotes synchronized gamma oscillations in hippocampal interneuron networks. Proc Natl Acad Sci U S A 99:13222-13227.

Binder DK, Croll SD, Gall CM, Scharfman HE (2001) BDNF and epilepsy: too much of a good thing? Trends Neurosci 24:47-53.

Cellerino A, Maffei L, Domenici L (1996) The distribution of brain-derived neurotrophic factor and its receptor trkB in parvalbumin-containing neurons of the rat visual cortex. Eur J Neurosci 8:1190-1197.

Chao MV (2003) Neurotrophins and their receptors: a convergence point for many signalling pathways. Nat Rev Neurosci 4:299-309.

Chen ZY, Jing D, Bath KG, Ieraci A, Khan T, Siao CJ, Herrera DG, Toth M, Yang C, McEwen BS, Hempstead BL, Lee FS (2006) Genetic variant BDNF (Val66Met) polymorphism alters anxiety-related behavior. Science 314:140-143.

Chevaleyre V, Castillo PE (2003) Heterosynaptic LTD of hippocampal GABAergic synapses: a novel role of endocannabinoids in regulating excitability. Neuron 38:461-472.

Dougherty KD, Milner TA (1999) p75NTR immunoreactivity in the rat dentate gyrus is mostly within presynaptic profiles but is also found in some astrocytic and postsynaptic profiles. J Comp Neurol 407:77-91.

Drasbek KR, Jensen K (2006) THIP, a hypnotic and antinociceptive drug, enhances an extrasynaptic GABA(A) receptor-mediated conductance in mouse neocortex. Cereb Cortex 16:1134-1141.

Elmariah SB, Crumling MA, Parsons TD, Balice-Gordon RJ (2004) Postsynaptic TrkB-mediated signaling modulates excitatory and inhibitory neurotransmitter receptor clustering at hippocampal synapses. J Neurosci 24:2380-2393.

Frerking M, Malenka RC, Nicoll RA (1998) Brain-derived neurotrophic factor (BDNF) modulates inhibitory, but not excitatory, transmission in the CA1 region of the hippocampus. J Neurophysiol 80:3383-3386.

Freund TF, Buzsáki G (1996) Interneurons of the hippocampus. Hippocampus 6:347-470.

Henneberger C, Jüttner R, Rothe T, Grantyn R (2002) Postsynaptic action of BDNF on GABAergic synaptic transmission in the superficial layers of the mouse superior colliculus. J Neurophysiol 88:595-603.

Jensen K, Mody I (2001) L-type Ca2 + channel-mediated short-term plasticity of GABAergic synapses. Nat Neurosci 4:975-976.

Klausberger T, Magill PJ, Márton LF, Roberts JD, Cobden PM, Buzsáki G, Somogyi P (2003) Brain-state- and cell-type-specific firing of hippocampal interneurons in vivo. Nature 421:844-848.

Knüsel B, Hefti F (1992) K-252 compounds: modulators of neurotrophin signal transduction. J Neurochem 59:1987-1996.

Lee KF, Li E, Huber LJ, Landis SC, Sharpe AH, Chao MV, Jaenisch R (1992) Targeted mutation of the gene encoding the low affinity NGF receptor p75 leads to deficits in the peripheral sensory nervous system. Cell 69:737-749.

Lu B, Pang PT, Woo NH (2005) The yin and yang of neurotrophin action. Nat Rev Neurosci 6:603-614.

Lyons WE, Mamounas LA, Ricaurte GA, Coppola V, Reid SW, Bora SH, Wihler C, Koliatsos VE, Tessarollo L (1999) Brain-derived neurotrophic 
factor-deficient mice develop aggressiveness and hyperphagia in conjunction with brain serotonergic abnormalities. Proc Natl Acad Sci U S A 96:15239-15244.

Matsumoto T, Rauskolb S, Polack M, Klose J, Kolbeck R, Korte M, Barde YA (2008) Biosynthesis and processing of endogenous BDNF: CNS neurons store and secrete BDNF, not pro-BDNF. Nat Neurosci 11:131-133.

Nagappan G, Zaitsev E, Senatorov VV Jr, Yang J, Hempstead BL, Lu B (2009) Control of extracellular cleavage of ProBDNF by high frequency neuronal activity. Proc Natl Acad Sci U S A 106:1267-1272.

Neves-Pereira M, Mundo E, Muglia P, King N, Macciardi F, Kennedy JL (2002) The brain-derived neurotrophic factor gene confers susceptibility to bipolar disorder: Evidence from a family-based association study. Am J Hum Genet 71:651-655.

Oliva AA Jr, Jiang M, Lam T, Smith KL, Swann JW (2000) Novel hippocampal interneuronal subtypes identified using transgenic mice that express green fluorescent protein in GABAergic interneurons. J Neurosci 20:3354-3568.

Olofsdotter K, Lindvall O, Asztély F (2000) Increased synaptic inhibition in dentate gyrus of mice with reduced levels of endogenous brain-derived neurotrophic factor. Neuroscience 101:531-539.

Pang PT, Teng HK, Zaitsev E, Woo NT, Sakata K, Zhen S, Teng KK, Yung WH, Hempstead BL, Lu B (2004) Cleavage of proBDNF by tPA/plasmin is essential for long-term hippocampal plasticity. Science 306:487-491.

Pillai A (2008) Brain-derived neurotropic factor/TrkB signaling in the pathogenesis and novel pharmacotherapy of schizophrenia. Neurosignals 16:183-193.

Rivera C, Li H, Thomas-Crusells J, Lahtinen H, Viitanen T, Nanobashvili A, Kokaia Z, Airaksinen MS, Voipio J, Kaila K, Saarma M (2002) BDNF- induced TrkB activation down-regulates the $\mathrm{K}^{+}-\mathrm{Cl}^{-}$cotransporter KCC2 and impairs neuronal $\mathrm{Cl}^{-}$extrusion. J Cell Biol 159:747-752.

Seidah NG, Benjannet S, Pareek S, Chrétien M, Murphy RA (1996) Cellular processing of the neurotrophin precursors of NT3 and BDNF by the mammalian proprotein convertases. FEBS Lett 379:247-250.

Shelton DL, Sutherland J, Gripp J, Camerato T, Armanini MP, Phillips HS, Carroll K, Spencer SD, Levinson AD (1995) Human trks: molecular cloning, tissue distribution, and expression of extracellular domain immunoadhesins. J Neurosci 15:477-491.

Soltesz I, Smetters DK, Mody I (1995) Tonic inhibition originates from synapses close to the soma. Neuron 14:1273-1283.

von Schack D, Casademunt E, Schweigreiter R, Meyer M, Bibel M, Dechant G (2001) Complete ablation of the neurotrophin receptor p75NTR causes defects both in the nervous and the vascular system. Nat Neurosci 4:977-978.

Wang JW, Dranovsky A, Hen R (2008) The when and where of BDNF and the antidepressant response. Biol Psychiatry 63:640-641.

Williams SR, Buhl EH, Mody I (1998) The dynamics of synchronized neurotransmitter release determined from compound spontaneous IPSCs in rat dentate granule neurones in vitro. J Physiol 510:477-497.

Woo NH, Lu B (2006) Regulation of cortical interneurons by neurotrophins: from development to cognitive disorders. Neuroscientist 12:43-56.

Woo NH, Teng HK, Siao CJ, Chiaruttini C, Pang PT, Milner TA, Hempstead BL, Lu B (2005) Activation of p75NTR by proBDNF facilitates hippocampal long-term depression. Nat Neurosci 8:1069-1077.

Yang J, Siao CJ, Nagappan G, Marinic T, Jing D, McGrath K, Chen ZY, Mark W, Tessarollo L, Lee FS, Lu B, Hempstead BL (2009) Neuronal release of proBDNF. Nat Neurosci 12:113-115. 